\title{
PECULIARITIES OF SELECTION OF INVESTMENT ARTWORKS
}

\author{
Daiva Jurevičienè, Božena Kostecka*
}

\section{Introduction}

Rapid economic development leads to the expansion of investment culture. Obviously, more and more people are inclined to choose a safer investment, review their investment portfolio, and diversify it with various investment tools to minimise risk and maximise the profitability of investment. One of such tools is art. It is important to grasp the details of the art market and investment artwork selection to invest successfully in artwork and get a high return on it.

While interest in alternative investment opportunities is growing rapidly, however, there is not much scientific literature analysing in detail the investment decision-making on the art market. This topic has not been widely examined in Lithuania either. Only popular literature or some single researchers interested in this topic can be found, such as Raškinis and Zigmantienė (2008), Jurevičienė and Savičenko (2011, 2012a, 2012b), and Jurevičienè, Miečinskienė and Savičenko (2012). Meanwhile, foreign scholars have written many articles about art as an investment tool. This topic is analysed by Baumol (1986), Frey and Pommerehne (1989) Frey and Cueni (2013), Goetzmann (1993, 2011), Goetzmann and Spiegel (1995), Mei and Moses (2002, 2005), Campbell (2004, 2008), Kraeussl and Lee (2010) and others. Scientists still have not agreed on how to choose an investment artwork and foresee the return on investment. Most investors make investment decisions intuitively through own experience.

The purpose of this article is to identify the specific features of the investment decision-making on the art market. To achieve this objective the article highlights investment characteristics of artworks, performs a review of art market trends of the last decade along with the price index forecast by art movements. The ARIMA forecasting method is applied to predict changes of art prices in 2014-2015 for the aggregate Artmarket Global index and for different art movements (old masters, impressionism and post-impressionism, modern art, contemporary art). The paper also examines a new art market index introduced by Charlin and Cifuentes in 2013. The ratio, called Artistic Power Value, based on the price of area per unit (US dollars per square centimetre), is applied to two-dimensional artworks. Based on the Artistic Power Value index, a comparison of selected artists' artworks is performed according to the picture position and the theme to show the benefits of this indicator for investment decision-making.

\footnotetext{
* Daiva Jurevičienè, Mykolas Romeris University Ateities, Faculty of Economics and Finance Management, Vilnius, Lithuania (daiva.jureviciene@mruni.eu); Božena Kostecka, UAB Ingenious IT, Vilnius, Lithuania (bozena.kostecka@inbox.lt).
} 


\section{The main dimensions of investment in arts}

The examination of studies of investment in arts shows that researchers evaluate this investment tool controversially. Baumol (1986) states that artwork prices are stochastic: high profits and high losses are possible when investing in art for a short term and the gains can be close to zero over a long term. The research of Frey and Pommerehne (1989), continuing from Baumol, has found that paintings of French impressionists, old masters and of the examined period from 1653 to 1987 are characterised by a very high return on investment. Scientists estimate that annual return on investment in paintings at that time was about 1.5 percent, while long-term investment returns amounted to 3 percent per year. Frey and Cueni (2013) drew attention to the fact that investment in works of art provided not only financial but also "spiritual" return. Mei and Moses $(2002,2005)$ advocated for investment in art. According to them, investing in art is much more profitable than investing in securities. According to Jakutis (2013) the return on investment in arts is difficult to predict because it is highly influenced by fashion trends but statistically these investments pay off in nine cases out of ten. An increasing number of market participants have adequately assessed the risks associated with the art market over the past decade. New technologies and innovations, as well as specialised services such as art banking, have significantly contributed to the transparency of the market and prediction of the potential investment value of art. The scientific literature highlights that investment risk is calculated in art, and it can be effectively managed (Karpinski, 2011).

Art market characteristics make it one of the most complex areas of investment but, at the same time, it offers broad operational capabilities. The main characteristics of the art market are presented in Figure 1.

\section{Figure1}

\section{The main characteristics of the art market}

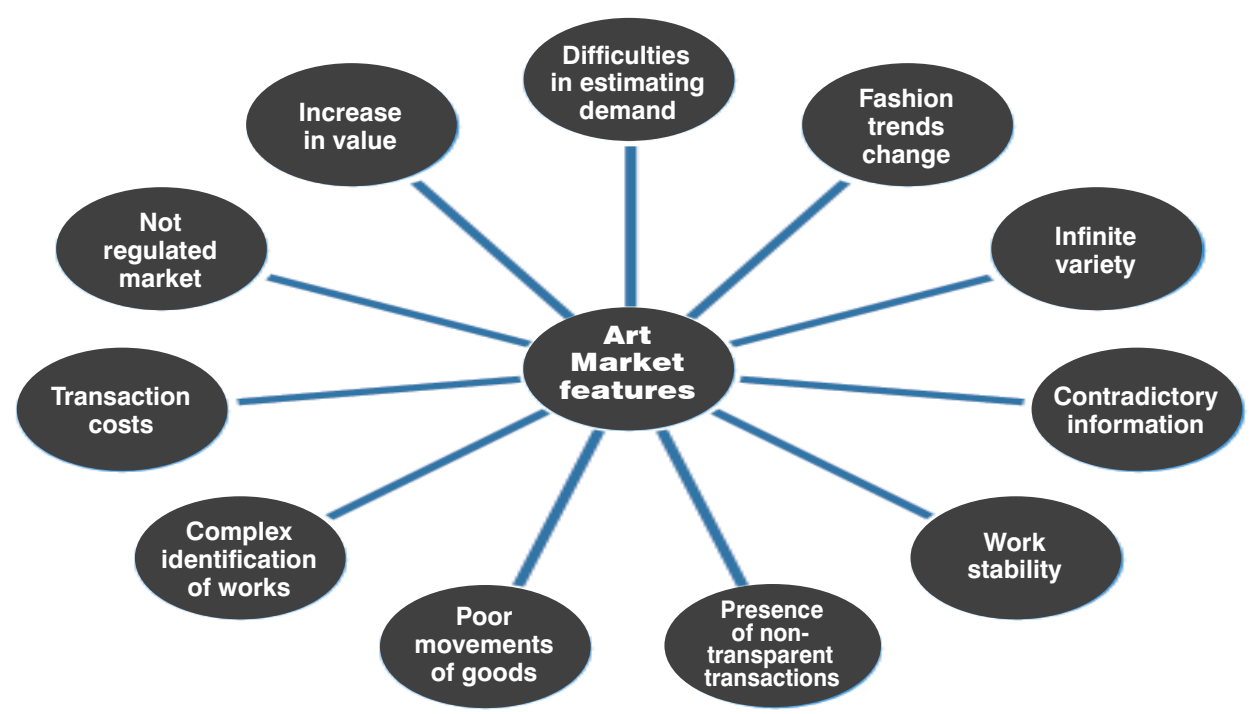

Source: compiled by the authors according to Beaulieu, 2008 
Educated persons in history invested a part of their money in arts and realised that this investment was viable, stable and earned 10-20 percent of annual returns. Raškinis and Zigmantienè (2008) distinguish pros and cons of investment in arts of which the most important advantages are low price volatility and low correlation with other investment tools. Meanwhile, in terms of deficiencies, low liquidity and high influence of fashion trends on investment returns are important; therefore, it is necessary to select less fashion-sensitive works. These features can be used to evaluate the investment risks. The higher the risk associated with the work of art, the higher the risk premium the investor will be able to gain at the time of sale. Therefore, the risk assessment has a significant impact on the evaluation of works of art. According to the Art Market Trends report (Artprice, 2010), value is determined by the artist's notoriety, so investing in a little known or completely unknown artist is more risky than investing in well-known artists. In one of the interviews, Fibak (2011) advises novice collectors to buy works only in places that are engaged in the sale of works of art, i.e., galleries, auctions and art fairs. This has two positive sides: it reduces the risk of purchase of useless works and helps prevent overpayment, which often occurs when buying a piece of art directly from the author: artists find it hard to part with their works, and so they can set too high a price.

Currently, the most expensive art pieces are sold at auctions, where the value is over 80 million US dollars. One of the most expensive works considered - Edvard Munch's "Scream" - was sold at an auction at New York Sotheby's for 119 million US dollars in 2012. The second most expensive painting is Pablo Picasso's "Nude, Green Leaves and Bust" - it was sold at an auction at Christie's for 106 million US dollars in 2010. The most expensive work sold not at an auction was Paul Cezanne's "Card Players". The Qatari royal family bought it for 259 million US dollars in 2011. In total there are five "Card Players" paintings, and they are stored in world famous museums (aipt.lt, 2012).

When deciding to invest in art, it is important to note which works of art were the most popular in recent times. A UK-based commercial art gallery "Fine Art Trade Guild" conducted a survey to determine the most popular topics in works of art (Table 1).

\section{Table 1}

\section{UK best-selling and not recommended works of art}

\begin{tabular}{|l|l|}
\hline Most popular artworks & Avoided artworks \\
\hline Classic landscapes & Portraits (with the exception of famous artists) \\
\hline Impressionistic landscapes & Art depicting prurient nakedness and violence \\
\hline Modern and abstract landscapes & Art depicting openly political, religious or cultural attitudes \\
\hline Marine, port and beach images & Works of art where the topics are vague and unclear \\
\hline Animals and plants & \\
\hline Nudes & \\
\hline
\end{tabular}

Source: compiled by the authors according to Artofprofits, 2007 
It is proposed to avoid investing in portraits as people are generally reluctant to hold unknown, casual personal images. However, it should be noted that this rule is not valid for works of famous artists. It is not recommended to invest in art depicting prurient nakedness and violence because such works can be unsalable among investors with high aesthetic perceptions. It is not advisable to invest in a work of art that openly depicts political, religious or cultural attitudes because this kind of work can be offensive to certain groups of people. And finally, works of art with vague and unclear topics - it is obvious that the market for such art is very narrow.

The art market has undergone a radical change over the last decade. In the recent past, customers and artists from the US and Europe heavily dominated the art market, but new art markets emerged around the world in the last decade. Currently, collectors, artists and art connoisseurs from all over the world comprise the global art market. Due to the emergence of art fairs, auctions and new online businesses and other market participants, the art market has more than doubled since 2002 (McAndrew, 2013). There are two strong trends that have showed up over the last decade (Karpinski, 2011):

- First of all, art trade patterns change, determined by the rapid development of the Internet, or, to be more specific, online sales. Introduction of new technologies is one of the key factors enabling the art market to take new challenges and opportunities. A growing number of data and research show that online transaction platforms open up new segments of the art market, characterised by lower prices and information availability. Traditional art market models are beginning to adapt to the dynamic environment.

- The second trend is a strong geopolitical change in the art market, related to China's expansion. China became the world's largest art auction market in 2011 influenced by the government policy, which provided free public museum attendance. Chinese artists quickly tied the price difference between the artists of the West thanks to the support of Chinese collectors.

Despite the growth of the art market, a slight decline is observed when comparing the outcomes of the global art market of the last two years (2011 and 2012). Based on the results of the global art market, the number of transactions fell by almost 4 percent, dropping from 36.8 million USD in 2011 to 35.5 million in 2012. The fact that the decline in the value of sales was greater than the decrease in the number of transactions shows that prices on some markets declined, and less work entered the market. Despite a slight decline in 2012 compared to the results of 2003, the art market is more than twice bigger in terms of both sales value and number of deals (McAndrew, 2013).

Various art movements differ due to popularity and profitability. The post-war and contemporary art auctions accounted for most of the turnover by the sales value in 2012 - entire 43 percent of the total value (Figure 2). 


\section{Figure 2}

Auction sales by category in 2012, \%

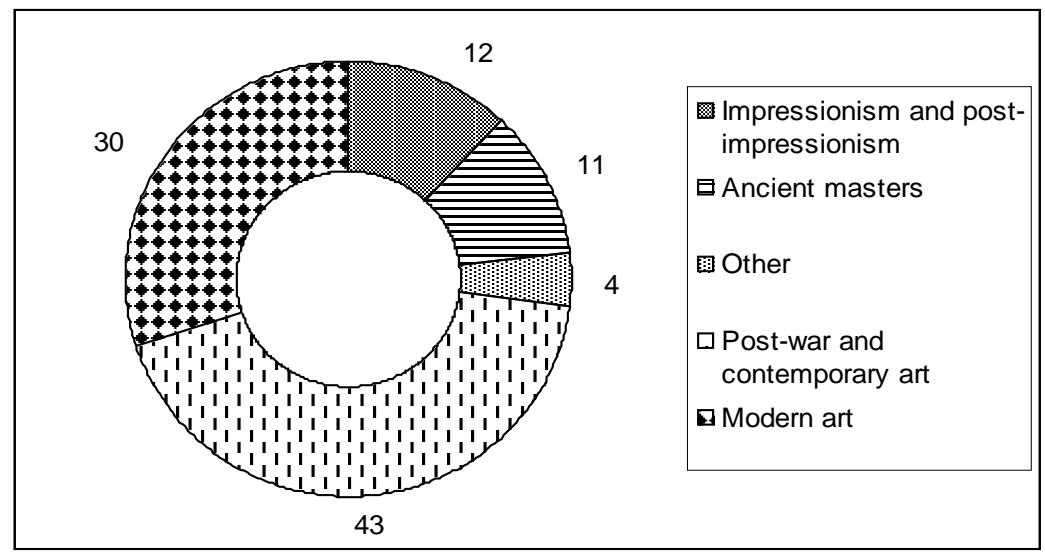

Source: McAndrew, 2013

This is partly due to the new buyers' contemporary taste and the desire to create a large collection of art in a short period of time. The supply of other traditional art market categories (old masters and impressionists) is unable to meet the demand of the market, since most of the works belong to museums and creators of such artworks have long been dead while the number of contemporary works of art continues to grow. Post-war and contemporary art as well as modern art together accounted for almost three-quarters of the total sales in 2012. The post-war and contemporary art market has been one of the fastest growing and most volatile markets in the last decade. During the period from 2003 to 2007, the market increased by more than 480 percent in terms of sales value and by about 150 percent in terms of sales volume, while modern art was one of the main targets of collectors and investors in the world. During this period, contemporary art established its prestige and became equal with the art of old masters and modern art, which has long been highly rated and regarded as prestigious. Nevertheless, it should be borne in mind that contemporary art does not provide such investment security as traditional art forms due to significant price volatility and sensitivity to fashion trends (McAndrew, 2013).

Artworks also depend on quality and artistic value. Prices of an artist's works created at different stages of his/her life can often vary significantly because usually the artist creates multifarious artistic values at different stages. Another important feature is that overall demand-supply laws have a significant impact on prices of works of art as well as on prices of other emotional investments. The art market is very limited, it is usually expressed in units, i.e., there is only one copy of a specific work of art. This is particularly true in the case of death of an artist as works become flat-rate; consequently, the prices of his/her artworks generally begin to grow rapidly (Campos and Barbose, 2008). Another feature is productivity. The per-work price of a prolific author is usually lower than that of a non-productive one, since a price increase is determined by the factors of rarity and uniqueness (Mikalajūnas, 2008). 
To sum up, it is very difficult to choose a valuable work of art. In order to invest successfully in artwork, many factors have to be taken into account. While there are a lot of talented artists in the world, many of their works are still not recognised and are not very valuable. The demand for works for which record amounts are paid as soon as they hit the art market and the value of which rises solely due to the name of an acclaimed artist is very high, but their supply is limited. However, art market analysts believe that a good understanding of the art market and the peculiarities of investment and mastering the art mechanism helps invest successfully and get a sufficiently high return.

\section{Price indices}

\subsection{Methodologies of index composition}

The question how to calculate the return on the art market receives the most attention from art market experts. It is a challenging task, not only because this market is characterised by low liquidity, at least compared to the shares or bonds markets, but also for its diversity - every work of art is a unique object. Investors in works of art use means similar to those of other market investors - a number of price indices and pricing methodologies. Renneboog and Spaenjers (2011), Higgs and Worthington (2005), Agnello and Pierce (1996), and Artnet Analytics (2012) base their calculations on the hedonic regression model, where the price goes down when works of art have certain characteristics. Works of art can have a full set of physical and intangible characteristics that determine the cost of the work, for example, the artist's name, his/her reputation, materials, time of creation, quality, etc. The hedonic method calculates a part of the price attributable to each of the elements, which may be important in determining the price of the work. This constitutes a set of performance indices that reflects the "standard work" price. According to Fase (2001), this is the most commonly used method to determine the return on art investment because it uses all the details of an auction, including works of art that have not been resold, and it could determine the price trends of artwork groups involved rather than individual works. Thus, such a model is suitable for managing a variety of products and using all available data. Application of this model may be impossible in the case of limited data (Galbraith and Hodgson, 2012).

The second option is application of re-sales regression. This method collects recurring sales of a particular work and composes an index based on the provided returns. This method can be applied only to those works of art that have been sold at least twice. However, a specific resale can occur only once in a century or not occur at all, which reduces the overall number of observations and is incorrectly reflected in the price index calculation. The advantage of this method is the use of one artwork price as data for analysis but it has two negative attributes: potential sampling bias and the fact that only a small subset of the possible data are used (Mei and Moses, 2002).

The geometric mean method is less common. Here, monitoring of auction prices of individual works forms a probability distribution of the price, which is used to calculate the price index for the entire collection. This method does not take into account the 
different art movements; all works of art are treated as equal, and it is assumed that all works are of equal quality; however, in many cases this assumption is not correct (Campbell, 2008).

Another possibility is the average cost method. In this case, the price index is created by calculating the average price. Application of this method is based on the creation of a "basket" of selected works and monitoring it over a period of time. If the piece remains unsold at the end of the period, its price is determined by expert judgment or the price of a close substitute (another work of the same artist, of similar size and quality). Subjectivity is one of the main drawbacks of this method (Kraeussl and Lee, 2010).

According to Ashenfelter and Graddy (2003), the estimated return using hedonic regression is about 4 percent, whereas the re-sale regression yields a rate of return of 9 percent. Thus, the question is which one is correct; which method calculates the return accurately still remains open. The four main methodologies mentioned above are used for the construction of an art price index (Campbell, 2008). The index can be defined as a statistical indicator showing the changes in the market and the economy. The index is used as a tool that reflects the general level of prices and price trends on the art market (analize.lt, 2013). Art price indices are useful for calculating the changes of art market prices and for evaluation of art as an investment tool compared with other asset classes. There are countless indices that reveal art market trends. The following main ratios of the art market are distinguished: Artnet Fine Art index; Mei and Moses Fine Art index; Sotheby's Art index; Short-term investment index; General Fine Art index; and Artprice Global index (Jurevičienè and Savičenko, 2012a).

It is difficult to assess art market items objectively and to compare them in time; consequently, both art price indices and composition methodologies are debatable topics. Chanel, Gerard-Varet and Ginsburgh (1996) argue that the use of different art index creation techniques and evaluation of data in the long run has revealed similar trends on the art market. Art analysts Mei and Moses (2005) claim that the art index based on the recurring sales regression is the most accurate and the most reliable one. Meanwhile, Kraeussl and Van Elsland (2008) argue that the sturdiest results are obtained using the hedonic model. In addition, it ensures that no objects with different characteristics are compared. These authors argue that indices constructed by hedonic regression can be considered in the context of the general financial market and can be used to simulate diversified investment portfolios. While these methods may be useful in econometric studies and to describe market trends, they are not very useful for investors. The main reason is that investors are interested in the actual rate of return rather than a statistical return of the market.

\subsection{Artprice Global index forecast}

The art market is unstable and its indicators are constantly changing; thus, art market experts try to predict future market trends. One way is to forecast the price index. Such a forecast could be the basis for investment decisions made by investors. Price index prediction is often used in time series analysis because prices can be described as a time-varying object. The ARIMA model is one of the most widely used time series 
analysis tools, and it was chosen for this investigation. According to Zhang (2003), the advantage of the ARIMA model is straightforward application using the appropriate software, the ability to adapt to changes in the data line, and stationarisation characteristics. Using this model, the prediction is performed with a $90 \%$ level of confidence. Other models were not investigated as there were no seasonal fluctuations observed in previous years.

ARIMA (AutoRegressive Integrated Moving Average) is sometimes called a Box-Jenkins model. Its essence is that it combines the approaches of autoregression, differentiation and moving averages. It is used for linear time series modelling (Pukènas, 2006). The most general ARIMA model consists of three parts and is expressed as follows: ARIMA ( $p, d, q$ ), where $p$ is the series of autoregression, $d$ is the series of differentiation, and $\mathrm{q}$ is the number of members of moving average ${ }^{1}$.

Due to the complexity of this method, its effective adaptation is possible only using special computer programs. After reviewing several statistical packages, the StatSoft product (STATISTICA statistical package) was chosen for analysing and forecasting art price indices. Applying the ARIMA forecasting model, a combined Artprice Global Index forecast and forecasts of different art movements (Old Masters, Impressionism and Post-Impressionism, Modern art and Contemporary art) were made. The input data include changes of the Artprice Global Index values from the first quarter of 1998 to the second quarter of 2013. Data were provided by the Artprice.com website and made on the basis of the Art and Design auction results. The forecast is made for two years (eight quarters).

The Old Masters index forecast is made by adapting the ARIMA $(5,1,1)^{2}$ model. The results are presented in Table 2.

\section{Table 2}

The forecast values of Old Masters Artprice Global Index

\begin{tabular}{|l|c|c|c|c|}
\hline & $\mathbf{1}^{\text {st }}$ quarter & 2 $^{\text {nd }}$ quarter & 3 $^{\text {rd }}$ quarter & $\mathbf{4}^{\text {th }}$ quarter \\
\hline $\mathbf{2 0 1 3}$ & & & & 117.3948 \\
\hline $\mathbf{2 0 1 4}$ & 114.1583 & 110.5770 & 114.3218 & 117.8241 \\
\hline $\mathbf{2 0 1 5}$ & 114.5876 & 111.0064 & 114.7511 & \\
\hline
\end{tabular}

Source: calculated by the authors

1 First, the stationarity of the process generating time series is determined according to the draw graph. The process is stationary if the median and dispersion is uniform over time. Indicating the stationary shape into the process, the value of parameter $d$ is determined that is equal to the number of differentiate procedure. Usually $\mathrm{d}$ is equal to 0 or 1 . Proper values of $\mathrm{p}$ and $\mathrm{q}$ are determined by functions of autocorrelation and partial correlation. The function of autocorrelation represents a sequence of values of the correlation coefficient of initial data and data pushed by a particular number of terms (Pukènas, 2006).

2 Meanings of $d, p$ and $q$ were chosen by the program automatically and differ for each art direction. 
According to the results, the Old Masters index will remain unstable. It is not surprising as historically the Old Masters market was one of the most unstable sectors on the global art market. Comparing to the latter years, it is predicted that the value of the index will gradually rise. It could be related to the fact that the number of Old Masters' works is limited, and the status of this market is represented by very high prices. Notwithstanding the fact that this art movement is considered a particular one, the obtained results show that the Old Masters market will prosper, but in the near future it will not reach the level of 2008, when the index value was the highest.

The Impressionism and Post-Impressionism index forecast is made by adapting the ARIMA $(2,1,2)$ model. The results are presented in Table 3.

\section{Table 3}

The forecast values of Impressionism and Post-Impressionism Artprice Global Index

\begin{tabular}{|l|c|c|c|c|}
\hline & $\mathbf{1}^{\text {st }}$ quarter & $\mathbf{2}^{\text {nd }}$ quarter & $\mathbf{3}^{\text {rd }}$ quarter & $\mathbf{4}^{\text {th }}$ quarter \\
\hline $\mathbf{2 0 1 3}$ & & & & 95.44547 \\
\hline $\mathbf{2 0 1 4}$ & 94.83439 & 95.03471 & 95.11846 & 95.78518 \\
\hline $\mathbf{2 0 1 5}$ & 95.17409 & 95.37441 & 95.45817 & \\
\hline
\end{tabular}

Source: calculated by the authors

The results show that the Impressionism and Post-Impressionism price index will remain stable, and its value is the lowest comparing to other analysed art movements. The results are not astonishing as this art sector is the smallest one in the art market. This art movement is represented by a small number of artists, and the number of works is more limited than in other sectors. Thus the price index of this sector is not fluctuating and the changes of forecasted index movement are least. On the other hand, this doesn't mean that there is no sense to invest in Impressionism and Post-Impressionism artworks, contrary, the artworks of this kind are among the most expensive works sold.

The modern art index forecast is made adapting the ARIMA $(2,1,2)$ model. The results are presented in Table 4.

\section{Table 4}

The forecasted values of Modern art Artprice Global Index

\begin{tabular}{|l|c|c|c|c|}
\hline & $\mathbf{1}^{\text {st }}$ quarter & $\mathbf{2}^{\text {nd }}$ quarter & $\mathbf{3}^{\text {rd }}$ quarter & $\mathbf{4}^{\text {th }}$ quarter \\
\hline $\mathbf{2 0 1 3}$ & & & & 134.2486 \\
\hline $\mathbf{2 0 1 4}$ & 137.5508 & 137.6154 & 138.2766 & 136.6533 \\
\hline $\mathbf{2 0 1 5}$ & 139.9555 & 140.02 & 140.6812 & \\
\hline
\end{tabular}

Source: calculated by the authors 
According to the forecasted price index values of the next two years we could state that ratios of the Modern art sector will gradually increase - it is predicted that the index will increase by more than 5 percent during the period from the end of 2013 to the end of 2015 .

The contemporary art index forecast is made adapting the ARIMA $(2,1,2)$ model. The results are presented in Table 5.

\section{Table 5}

The forecasted values of Contemporary art Artprice Global Index

\begin{tabular}{|l|c|c|c|c|}
\hline & $\mathbf{1}^{\text {st }}$ quarter & $\mathbf{2}^{\text {nd }}$ quarter & $\mathbf{3}^{\text {rd }}$ quarter & $\mathbf{4}^{\text {th }}$ quarter \\
\hline $\mathbf{2 0 1 3}$ & & & & 193.2602 \\
\hline $\mathbf{2 0 1 4}$ & 199.3521 & 203.7791 & 206.8292 & 199.4623 \\
\hline $\mathbf{2 0 1 5}$ & 205.5542 & 209.9812 & 213.0313 & \\
\hline
\end{tabular}

Source: calculated by authors

The results show that the Contemporary art price index will increase the most - during the period from the end of 2013 to the end of 2015, it will increase by nearly 10 percent. This could be explained by fashion trends and the changing fancy of investors. Above all, a modern investor wants to have a "trademark" on the wall identifiable at once without going too deep into its historic value. Contemporary artists curry favour with such collecting habits, making pictures and sculptures that buyers are willing to purchase instantly recognisable. It maintains the balance between supply and demand in the contemporary art sector.

Summarised general and different forecasting results of Artprice Global indices of art movements are presented in Figure 3. The obtained results show that the Artprice Global Index will vary unstably over the next few years, keeping the 2012 level. Despite volatility, the index will tend to increase - in the first quarter of 2015, the index value will increase by about 2.8 percent compared with the first quarter of 2014 and by about 6.9 percent compared with the first quarter of 2013. Results for other quarters have a similar trend.

Figure 3 shows that Contemporary art outperforms other art movements. The second is Modern art, and the third is the art of the Old Masters. Impressionism and Post-Impressionism have the lowest values of the index. It can be concluded that art indices of different art movements evolve differently. Modern art and Contemporary art indices remain the most stable and slightly increasing, while the Old Masters' index is forecast to be the most unstable. The Impressionist and Post-Impressionist, and the Old Masters art movements have the lowest index value - these art movements cannot provide enough supply to meet the demand of the market since most of the works belong to museums and authors of these arts have long been dead, so collections of their works have a fixed size. Meanwhile, the Contemporary art index value is the highest because this art movement continues to grow, satisfying the market demand. 


\section{Figure 3}

\section{Comparison of forecasts of Artprice Global indices for different art movements for 2013-2015}

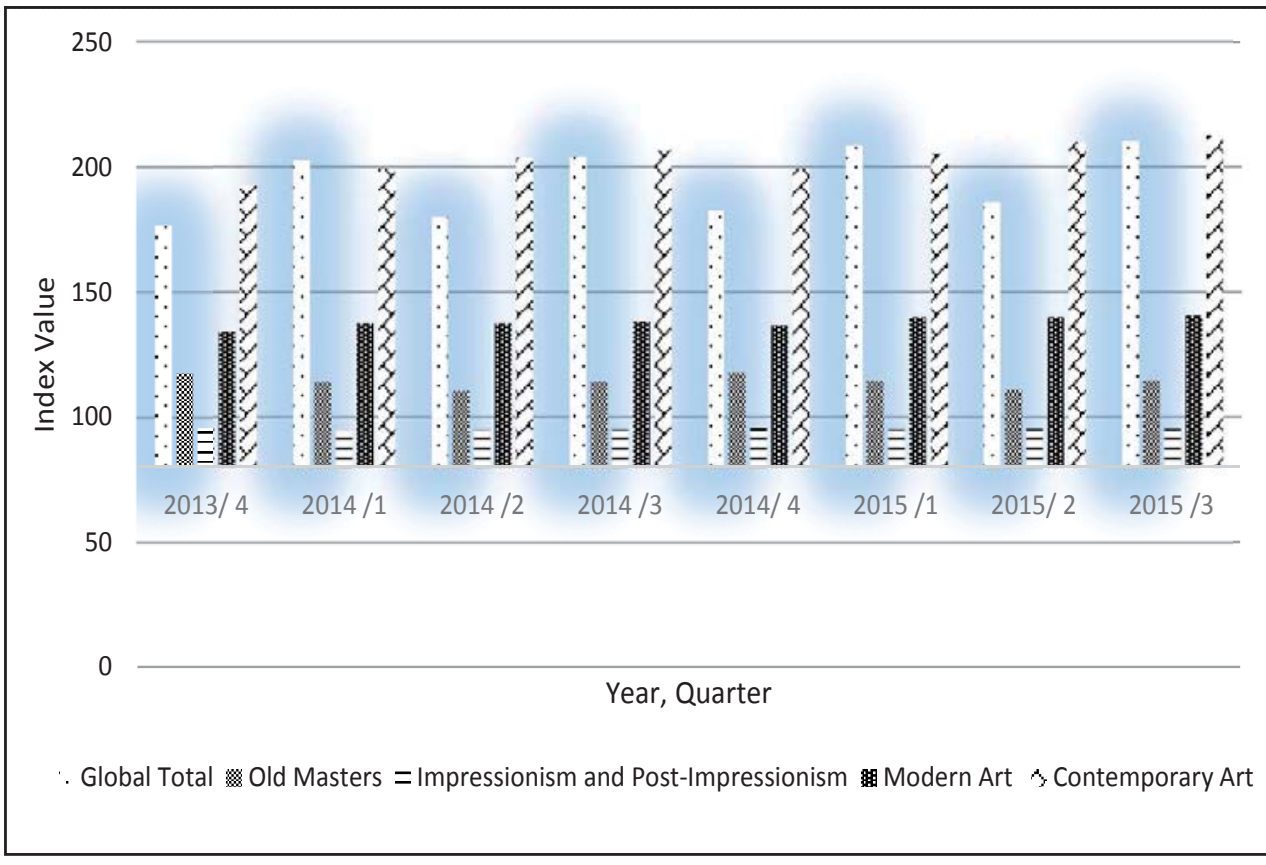

Source: calculated by authors

Investments in Modern Art and in Contemporary Art tend to increase (Fig. 3), and this means that investing in these types of art will be profitable in the nearest future.

\section{Art price analysis using Artistic Power Value}

The art price index forecast can give a general trend of the art movement, but it does not tell the investor whether it is worth investing in a particular field and in a particular artwork, what the risk of the investment is, and what return can be expected from such an investment. Thus, this prediction could be useful to art market researchers, but to for investors, whose goal is to select a specific work of art suitable for investment as well as to predict the return of such an investment. So, the new art market index, called Artistic Power Value (APV), will be more useful. It is based on the price per area unit (dollars per square centimetre), and it is applied to two-dimensional works of art such as paintings. In addition to its intuitive use and simple calculations, this figure has more advantages for investors. It makes it easier to evaluate different artists in a range of prices, to compare them, and to observe the evolution of artists' creativity over time. Furthermore, the APV index facilitates the process of return evaluation (Charlin and Cifuentes, 2013). Some experts think that this figure does not take into account the individuality of each piece of art and diminishes the artistic process. However, the 
authors argue that this indicator has the advantage of facilitating market analysis the APV allows the calculation of economic value of art objects and can be used as a "unified price".

To calculate the APV index, the following artwork data is required: the image size (length and width) and the price. The input data for the research was obtained from artsalesindex.artinfo.com. This database was chosen because it was one of the publicly available and free databases. Artists were chosen at random, one from each different art movement. The main criterion for the selection of artists was a sufficient number of observations. Representatives of four different art movements were chosen for this research:

- The Old Masters - American Benjamin West (1738-1820), 431 sales;

- Impressionism and Post-Impressionism - French Gustave Caillebotte (1848-1894), 238 sales;

- Modern art - Canadian Emily Carr (1871-1945), 426 sales;

- Contemporary art - Mexican Javier Arevalo (1937-present), 45 sales;

- To investigate the impact of the number of factors on the prices of paintings, comparisons of APV indices were conducted based on the following indicators;

- Orientation of the painting: portrait or landscape;

- Theme of the painting: landscape scenery or not;

- Theme of the painting: shows a person (a few people) or people are not shown.

The aim of the study is to demonstrate the benefits of the APV index for investors (not to find the most profitable art movement). Through this index, an investor can compare several artists or one artist's paintings in order to clarify which piece of art has a higher value. Calculations and results are summarised in tables - it is convenient to rank the artists before making an investment decision and it may also be useful for valuation purposes of works of art. The data were sorted according to certain characteristics. To carry out the first part of the study, two separate data sets for each of the artist are needed. The first data set consists of data on portrait-oriented paintings, while the second one consists of data on landscape-oriented paintings. Table 6 provides APV median comparison results according to the orientation of the paintings. An interesting trend was found - all the artists analysed preferred paintings in the landscape position. Also, in all the cases, landscape-oriented paintings have a higher APV index and hence a higher price. Investing in these artists' works choosing a landscape-oriented painting will likely give higher returns than choosing a portrait-oriented one. 


\section{Table 6}

APV median comparison: landscape vs. portrait orientation of paintings by artists

\begin{tabular}{|c|c|c|c|c|c|}
\hline & \multicolumn{2}{|c|}{ Portrait-oriented paintings } & \multicolumn{2}{|c|}{$\begin{array}{l}\text { Landscape-oriented } \\
\text { paintings }\end{array}$} & \multirow{2}{*}{$\begin{array}{l}\text { Difference between portrait- } \\
\text { oriented and landscape- } \\
\text { oriented paintings } \\
\text { in APV median } \\
\text { (dollars } / \mathrm{cm}^{2} \text { ) }\end{array}$} \\
\hline & $\begin{array}{l}\text { Number } \\
\text { of sales }\end{array}$ & $\begin{array}{l}\text { APV median } \\
\text { (dollars } / \mathrm{cm}^{2} \text { ) }\end{array}$ & $\begin{array}{l}\text { Number } \\
\text { of sales }\end{array}$ & $\begin{array}{l}\text { APV median } \\
\text { (dollars/cm²) }\end{array}$ & \\
\hline Benjamin West & 185 & 29.11 & 225 & 36.98 & -7.87 \\
\hline $\begin{array}{l}\text { Gustave } \\
\text { Caillebotte }\end{array}$ & 81 & 213.43 & 149 & 264.95 & -51.52 \\
\hline Emily Carr & 153 & 122.14 & 215 & 135.40 & -13.26 \\
\hline Javier Arevalo & 18 & 1.05 & 27 & 1.23 & -0.18 \\
\hline
\end{tabular}

Source: calculated by authors. Note: pictures where the length is equal to the width were not analysed in this study

For APV comparison based on the paintings' themes, two separate data sets for each artist were made: the first data set consists of information about landscapes, the second one consists of data on all other pictures. Table 7 shows the APV median comparison results made based on the theme of the painting. Calculations show that Emily Carr's works dominated in landscapes, while Benjamin West, Gustave Caillebotte and Javier Arevalo works dominated in other subjects; their landscapes' APV index is lower than the APV for other works. In Emily Carr's case, the amount of landscapes and the APV rate greatly exceed the amount of other themes and their APV. It can be concluded that the artist was more successful in painting pictures of this genre, so they are sold more expensively, and it is likely that they will bring a better return to investors than the same artist's works on other themes.

\section{Table 7}

\section{APV median comparison: based on theme - landscape vs. not landscape}

\begin{tabular}{|c|c|c|c|c|c|}
\hline & \multicolumn{2}{|c|}{ Theme: landscape } & \multicolumn{2}{|c|}{ Theme: not landscape } & \multirow{2}{*}{$\begin{array}{l}\text { Difference between } \\
\text { landscapes and not } \\
\text { landscapes in APV } \\
\text { median (dollars } / \mathrm{cm}^{2} \text { ) }\end{array}$} \\
\hline & $\begin{array}{l}\text { Number } \\
\text { of sales }\end{array}$ & $\begin{array}{l}\text { APV median } \\
\text { (dollars } / \mathbf{c m}^{2} \text { ) }\end{array}$ & $\begin{array}{l}\text { Number } \\
\text { of sales }\end{array}$ & $\begin{array}{l}\text { APV median } \\
\text { (dollars } / \mathbf{c m}^{2} \text { ) }\end{array}$ & \\
\hline Benjamin West & 134 & 31.62 & 297 & 34.77 & -3.15 \\
\hline $\begin{array}{l}\text { Gustave } \\
\text { Caillebotte }\end{array}$ & 112 & 198.97 & 126 & 241.15 & -42.18 \\
\hline Emily Carr & 278 & 132.23 & 122 & 98.16 & 34.07 \\
\hline Javier Arevalo & 5 & 0.96 & 40 & 1.38 & -0.42 \\
\hline
\end{tabular}

Source: calculated by the authors

Similarly to the cases described above, two separate data sets for each artist were made for APV comparison based on painting themes. The first data set consists of information about paintings that depict a person or a few people, the second one consists of data on all other pictures. Table 8 shows APV median comparison results made based on painting themes. It can be noted that Benjamin West and Gustave Caille- 
botte's works were dominated by paintings depicting people, while Emily Carr and Javier Arevalo's paintings were dominated by other themes (Emily Carr painted more landscapes; Javier Arevalo's works are mostly abstract art); their paintings with people have lower APV indices than other works. Based on the fact that Benjamin West and Gustave Caillebotte's paintings with people have greater indices than paintings of other themes, it can be said that it is worth investing in these two artists' portraits - it is likely that they will bring a better return than other paintings of these artists.

\section{Table 8}

APV median comparison: based on theme - paintings of one or more persons vs. without people

\begin{tabular}{|c|c|c|c|c|c|}
\hline & \multicolumn{2}{|c|}{$\begin{array}{l}\text { Theme: there are one or more } \\
\text { persons in the painting }\end{array}$} & \multicolumn{2}{|c|}{$\begin{array}{l}\text { Theme: there are no people } \\
\text { in the painting }\end{array}$} & \multirow{2}{*}{$\begin{array}{l}\text { Difference between } \\
\text { paintings with people and } \\
\text { paintings with no people } \\
\text { in APV median } \\
\text { (dollars } / \mathrm{cm}^{2} \text { ) }\end{array}$} \\
\hline & $\begin{array}{l}\text { Number of } \\
\text { sales }\end{array}$ & $\begin{array}{l}\text { APV median } \\
\text { (dollars } / \mathrm{cm}^{2} \text { ) }\end{array}$ & $\begin{array}{c}\text { Number of } \\
\text { sales }\end{array}$ & $\begin{array}{l}\text { APV median } \\
\text { (dollars } / \mathrm{cm}^{2} \text { ) }\end{array}$ & \\
\hline Benjamin West & 265 & 39.11 & 166 & 31.93 & 7.18 \\
\hline $\begin{array}{l}\text { Gustave } \\
\text { Caillebotte }\end{array}$ & 138 & 238.97 & 100 & 198.51 & 40.46 \\
\hline Emily Carr & 98 & 97.45 & 302 & 130.87 & -33.42 \\
\hline Javier Arevalo & 8 & 0.91 & 37 & 1.28 & -0.37 \\
\hline
\end{tabular}

Source: calculated by the authors

In summary, the study may suggest that the APV index can analyse data in different sections, giving investors a convenient and simple aid in making investment decisions. Unlike other price indices, which only provide a general trend of the arts, this index may be a response to an investor's question whether it is worth investing in a specific work of art.

\section{Generalisations}

After making the analysis of theoretical aspects of investing in art and the art index forecast, the following peculiarities of investment decision-making on the art market can be distinguished:

- Take into account the major theoretical aspects of investing in art. It must be borne in mind that the liquidity of artworks is more than one year. In order to get the maximum benefit, longer investment maturities are required (from 7 to 10 years). It is better to invest during economic downturns or crises, when prices on luxury goods markets, including artworks, fall. While choosing an artwork, it is advisable to consult experts or gallery owners; it is necessary to follow fashion trends and be interested in auction results, which have the greatest impact on the art market: they can affect both prices and consumer behaviour.

- Take into account investment characteristics of artworks. It is important to clarify what the best-selling picture themes are. It is advisable to look at the ratings of the 
most expensive artworks and the most popular artists. It is also necessary to take into account the artist's popularity and reputation.

- Analyse past art market indicators according to different art movements to distinguish the most profitable art movement. The global art market review for the last decade shows that contemporary and modern art constitutes a major proportion of the total value of the art market.

- Conduct the price index forecast by the art movement to figure out which art movement indicators are favourable for profitable investments. Using the Artprice Global index forecast with the help of the ARIMA forecasting model, it was found that modern and contemporary art indices remain the most stable, while the index of old masters' art will be the most unstable. The index of contemporary art has the highest value of all the art movements analysed.

- Conduct a comparison of artworks in various dimensions using the APV index. Unlike other price indices, which only reflect a general trend of the art sector, this ratio may be a response to an investor's question whether it is worth investing in a particular artwork. Using this indicator, the investor can compare several artists or several paintings by one artist to clarify which artwork has a higher value.

\section{Conclusions}

Art, like any other investment tool, has both advantages and disadvantages, so there is no unanimous opinion about this investment. It is clear that before investing in art, it is necessary to evaluate the positive and negative sides and assess the risks. In order to invest successfully in an artwork and to get high returns, it is needed to grasp the details of the art market and peculiarities of choices of investment artworks.

Based on the analysis of art trends by art movements, it can be concluded that all art movements have responded similarly to changes in the economy in the past decade. The art movement trends analysis has shown that contemporary and modern art constitutes a major proportion of the total value of the art market. Traditional art movements, such as the art of the Old Masters, Impressionism and Post-Impressionism, cannot offer enough supply as the potential demand (or to meet the potential demand), while the contemporary art sector is constantly supplemented with new works, thus upholding the demand and increasing sales.

After the review of the price indices, it can be concluded that all the methods analysed can be useful in econometric studies and can describe market trends, but they are not very useful for investors. The main reason is that investors are interested in sales revenue of a particular artwork, but not in the return on the market.

A two-part investigation of art market trends was carried out in this paper. Applying the ARIMA forecasting model, a general Artprice Global Index forecast and the forecast according to different art movements were conducted. The Artprice Global Index forecast by art movements has shown that the Modern Art and Contemporary Art indices tend to rise, so probably investment in them will be profitable. The art price index forecast can provide a general trend of the arts sector, but it does not tell investors 
whether it is worth investing in a particular art movement or a particular artwork. Thus, this prediction could be useful to art market researchers, but not to investors.

In order to investigate impact factors on prices of paintings, a comparison of the APV index in several ways was performed: a comparison of the median APV of paintings according to picture orientation and theme. It can be concluded that based on this indicator, investors can choose among several artists or one artist's paintings to find which works of art have a higher value.

After the analysis of theoretical aspects of investment in art and after the index forecast, the following peculiarities of selecting artworks for investors were distinguished: an investor should consider the basic theoretical dimensions of art and investment properties of art, analyse past market indicators according to different art movements, asses price index forecast results by the art movement to figure out which art sector is favourable for profitable investments, and make a comparison of artworks by various features using the APV index.

Further research could focus on the APV indicator as its reliability and applicability has not been sufficiently investigated. The possibility of adapting the APV index to three-dimensional works of art (e.g., sculptures) as the price per volume unit (US dollars per cubic centimetre) could be considered.

\section{References}

AGNELLO, R. J.; PIERCE R. K. 1996. Financial Returns, Price Determinants, and Genre Effects in American Art Investment. Journal of Cultural Economics, 1996, vol. 20, no. 4, pp. 359-383.

AIPT.LT. Investavimas i meną. Brangiausi dailès kūriniai. 2012. http://aipt.lt/index.php/alternatyva/item/ 304-investavimas-\%C4\%AF-men\%C4\%85-brangiausi-dail\%C4\%97s-k\%C5\%ABriniai [cit. 2013.09.05].

ANALIZE.LT. Vertybinių popierių biržų indeksai ir jų samprata. 2013. http://analize.lt/component/content/ article/18-vp-indeksu-analize/vp-indeksai/9-vertybiniu-popieriu-birzu-indeksai-ir-ju-samprata.html [cit. 2013.09.05].

ARTNET ANALYTICS. Artnet Indices White Paper. 2012. http://www.artnet.com/analytics/reports/white-paper [cit.2013.10.05].

ARTPRICE. Art Market Trends. 2010. http://imgpublic.artprice.com/pdf/trends2010_en.pdf [cit. 2013.10.08].

ARTOFPROFITS. Art Investment: The Best and Worst Selling Subjects Revealed. 2007. http://www. artmarketblog.com/2007/08/20/art-investment-the-best-and-worst-selling-subjects-revealed/ [cit. 2013.10.08].

ASHENFELTER, O.; GRADDY, K. 2003. Auctions and the Price of Art. Journal of Economic Literature, 2003, vol. 41, no. 3, pp. 763-786.

BAUMOL, W. J. 1986. Unnatural Value: or Art Investment as Floating Crap Game, 1986. The American Economic Review, 1986, vol. 76, no. 2, pp. 10-14.

BEAULIEU, P. Art Investment Funds and Financial Centres: Opportunities for Development. Deloitte, 2008. http://www.deloitte.com/assets/Dcom-Luxembourg/Local\%20Assets/Documents/Artandfinance/2008/lu_strategicdiscussionpaper_092008.pdf [cit. 2013.11.08].

CAMPBELL, R. The Art of Portfolio Diversifications. 2004. http://www.fdewb.unimaas.nl/finance/faculty/ Campbell/images/Art proc.20Investment.pdf [cit. 2013.10.08].

CAMPBELL, R. 2008. Art as a Financial Investment. The Journal of Alternative Investments. Spring, 2008, vol. 10, no. 4, pp. 64-81. https://kunstmarktanalysen.com/uploads/publications/pdf/Campbell.pdf [cit. 2013.10.08]. 
CAMPOS, N; BARBOSE, R. L. Paintings and Numbers. 2008. An Econometric Investigation of Sales Rates, Prices and Returns in Latin American Art Auctions. The Institute for the Study of Labor: Discussion Paper Series. 2008, no. 3445. http://ftp.iza.org/dp3445.pdf [cit. 2013. 10.08].

CHANEL, O.; GERARD-VARET, L. A.; GINSBURGH, V. 1996. The Relevance of Hedonic Price Indices: The Case of Paintings. Journal of Cultural Economics, 1996, vol. 20, no. 1, pp. 1-24.

CHARLIN, V.; CIFUENTES, A. A. 2013. New Financial Metric for the Art Market. http://arxiv.org/ftp/arxiv/papers/1309/1309.6929.pdf [cit. 2013.11.20].

FASE, M. M. G. 2001. Investing in Art: a Blend of Financial Reward and Psychic Income. Netherlands Central Bank, Research Department, 2001.

FIBAK, W. 2011. Jak i co kolekcjonować - ekskluzywny wywiad. http://luxclub.pl/kat,1016267,wid,10521906, wiadomosc.html?_ticrsn=3andticaid=6c6d6 [cit. 2013.05.20].

FREY, B. S.; POMMEREHNE, W. W. 1989. Art Investment: An Empirical Inquiry. Southern Economic Journal, 1989, vol. 56, no. 2, pp. 396-409.

FREY, B. S.; CUENI, R. 2013. Why invest in art? The Economists' Voice, 2013, vol. 10, no. 1, pp. 1-6. http://www. bsfrey.ch/articles/C_567_2013.pdf [cit. 2013.11.20].

GALBRAITH, J. W.; HODGSON, D. 2012. Dimension Reduction and Model Averaging for Estimation of Artists' Age-Valuation Profiles. European Economic Review, 2012, vol. 56, no. 3, pp. 422-435.

GOETZMANN, W. N. 1993. Accounting for Taste: Art and the Financial Markets Over Three Centuries. The American Economic Review, 1993, vol. 83, no. 5, pp. 1370-1376. http://www.jstor.org/discover/10.2307/2117568?uid=3738480anduid=2anduid=4andsid=21103056390847 [cit. 2013.05.15].

GOETZMANN, W. N.; SPIEGEL, M. 1995. Private Value Components, and the Winner's Curse in an Art Index. European Economic Review, 1995, vol. 39, pp. 549-555.

GOETZMANN, W. N. Art and Money. 2011. http://aahvs.duke.edu/uploads/media_items/goetzmann-et-al-2011.original.pdf [cit. 2013.05.20].

HIGGS, H., WORTHINGTON, A. C. 2005. Financial Returns and Price Determinants in the Australian Art Market. The Economic Record, 2005, vol. 81, no. 253, pp. 113-123.

JAKUTIS, R. Apie kolekcijas. 2013. http://www.snaujienos.lt/naujienos/mes-tokie/30866-apie-kolekcijas [cit. 2013.09.18].

JUREVIČIENĖ, D.; SAVIČENKO, J. 2012. Art Investments for Portfolio Diversification. Intelektiné ekonomika, 2012(a), vol. 6, no. 2(14), pp. 41-56.

JUREVIČIENĖ,D.;SAVIČENKO,J.2012.ArtasViablelnvestmentTool.InternationalDaysofStatisticsandEconomics: conference proceedings: September 13-15, 2012. Vysoká škola ekonomická. Slaný:Melandrium, 2012(b). pp. 507-518.

JUREVIČIENĖ, D.; SAVIČENKO, J. 2011. Trends of Investments in Art. Economics and Management = Ekonomika ir vadyba. Kaunas University of Technology. Kaunas : Technologija. 2011. no. 16, pp. 1115-1123.

JUREVIČIENĖ, D.; MIEČINSKIENĖ, A.; SAVIČENKO, J. 2012. Art as a diversification tool of investment portfolios. The 7th international scientific conference "Business and Management 2012": selected papers. Vilnius Gediminas Technical University. Vilnius : Technika, 2012, pp. 84-91.

KARPINSKI, B. 2011. Obrót Dziełami Sztuki w Państwach Unii Europejskiej i w Krajach Trzecich Jako Forma Inwestycji i Tezauryzacji Pieniądza: master thesis : Gdańsk, Uniwersytet Gdański, 2011, p. 74.

http://www.smashwords.com\%2Fbooks\%2Fdownload\%2F271926\%2F1\%2Flatest\%2F0\%2F0\%2Fobrot-dzielami-sztuki-w-panstwach-unii-europejskiej-i-w-krajach-trzecich-jako-forma-inwestycji-i-tezauryzacji-pieniadza.pdfandei=BLGhUpz2EaqG4AS-zoH4CQandusg=AFQjCNFMJZI5e0ZIp9PmKs4IXWvp-S6mXg [cit. 2013.08.17].

KRAEUSSL, R.; LEE, J. 2010. Art as an Investment: the Top 500 Artists, VU University Amsterdam. https:// artmarketanalyses.com/uploads/publications/pdf/Kraeussl\%202.pdf [cit. 2013.08.10].

KRAEUSSL, R.; VAN ELSLAND, N. 2008. Constructing the True Art Market Index - A Novel 2-Step Hedonic Approach and its Application to the German Art Market. CFS Working Paper. 2008, no. 11. 
McANDREW, C. TEFAF Art Market Report. 2013. http://www.artfair.fr/wp-content/uploads/2013/05/TEFAF-AMR-2013-binnen-V4-DEF_LR.pdf [cit. 2013.09.09].

MEI, J.; MOSES, M. 2002. Art as an Investment and the Underperformance of Masterpieces. The American Economic Review, 2002, vol. 92, no. 5, pp. 1656-1668 http://pages.stern.nyu.edu/ jmei/artgood.pdf [cit. 2013.09.05].

MEI, J.; MOSES, M. Beautiful Asset: Art as Investment. 2005. http://www.wu.ac.at/cems/gc/whatwedo/bridging/symposia/2006/slides-papers/moses-mei.pdf [cit. 2013.09.15].

MIKALAJŪNAS, V. 2008. Meno kūriniai - netikèta išeitis išgąsdintiems recesijos. Investuok, 2008, no. 3, pp. 44-46.

PUKĖNAS, K. 2006. Laiko eilučių prognozavimas su SPSS, Decision Time \& Whatlf? Lietuvos Kūno Kultūros Akademija, 2006, p. 87.

RAŠKINIS, D.; ZIGMATIENĖ, S. 2008. Meno kūriniu, kaip potencialios investicinio portfolio diversifikavimo priemonès, vertinimas, Taikomoji Ekonomika: Sisteminiai tyrimai, 2008, pp.115-134.

RENNEBOOG, L.; SPAENJERS, C. 2011. The Iconic Boom in Modern Russian art. Journal of Alternative Investments, 2011, vol. 13, no. 3, pp. 67-80.

ZHANG, G. P. 2003. Time series forecasting using a hybrid ARIMA and neural network model. Neurocomputing, 2003, no. 50, pp. 159-175.

\title{
PECULIARITIES OF SELECTION OF INVESTMENT ARTWORKS
}

\begin{abstract}
The article deals with the art market and key dimensions of investment in art and distinguishes the peculiarities of selection of artworks for investment purposes, covering the main features of the art market. Methodologies of composition of art price indices are analysed. An art market trend analysis is conducted based on statistical data and variations of the Artmarket Global index for the last decade. Using the ARIMA forecasting method, the forecast of artwork price changes in 2014-2015 is conducted. The forecast is presented for the aggregate Artmarket Global index and for different art movements (old masters, impressionism and post-impressionism, modern art, contemporary art) to figure out which of them are the best for investments in the near future. The paper further investigates a new Artistic Power Value (APV) ratio and its adequacy for analysis which makes it easy to assess the suitability of investment in artworks and to compare works of art from various sections. Finally, investment decision-making characteristics of the art market are distinguished.
\end{abstract}

Key words: Art market, investing in artwork, art market trends, art price index forecast.

JEL classification: D14, D31, G11. 